\title{
Sero-Epizootiological Study of Racehorses with Pyrexia in the Training Centers of the Japan Racing Association
}

\author{
Takeo SUGIURA, Tomio MATSUMURA, Yoshio FUKUNAGA, and Kiyoshi HIRASAWA \\ Epizootic Research Station, Equine Research Institute, Japan Racing Association. 1400-4 Shiba, Kokubunji-machi, \\ Tochigi 329-04, Japan
}

(Received 21 October 1986/Accepted 3 September 1987)

\begin{abstract}
A sero-epizootiological study was conducted on horses which showed clinical pyrexia at two training centers, each of which maintained 1,200 to 2,100 racehorses for training, of the Japan Racing Association. It continued from 1980 to 1985 to clarify the cause of pyrexia, so that measures might be considered for the prevention of infectious disease. A total of 3,849 horses were found to be affected with pyrexia for the 6 years. Of them, 2,852 horses were tested to equine herpesvirus type 1 (EHV-1), equine rhinovirus type $1(\mathrm{ERhV}-1)$, rotavirus and equine adenovirus (EAdV) by collecting paired serum samples. As a result, $669(23.5 \%)$ horses showed seroconversion to these viruses; that is, 491 horses $(73.4 \%)$ to EHV-1, $91(13.6 \%)$ to ERhV-1, 64 (9.6\%) to rotavirus and $23(3.4 \%)$ to EAdV. EHV-1, ERhV-1 and rotavirus exhibited a seasonal characteristic in spread. EHV-1 and rotavirus spread in winter and early spring. ERhV-1 spread not only in the cold season, but in changing times of season, such as early spring and early autumn. The percentage of 3 years old in the horses showing seroconversion to EHV-1 was two times higher than those in the horses showing seroconversion to other viruses. All of the horses showing seroconversion to ERhV-1 and EAdV were under 4 or 3 years old, respectively. The mean age of the horses showing seroconversion to EHV-1, rotavirus, ERhV-1 and EAdV were 2.96, 2.73, 2.44 and 2.25 , respectively.-KEY wORDS: herpesvirus, horse, pyrexia, rhinovirus, sero-epizootiology.
\end{abstract}

The Japan Racing Association (J. R. A.) has two training centers (T. C.). Racehorses are transported to race courses from T. C. every time for each race. In contrast to functional convenience, such concentrated accomodation system as the T. C. inevitably harbors great risk of inducing infectious diseases. Actually, on account of a largescale epizootic of equine influenza over a period from December, 1971 to January, 1972 [19], horse races were canceled for two months around this period. Also, the spread of Getah virus infection interfered the horse races, because training was suspended in a number of horses in 1978 [7]. From these experiences, all of the racehorses are injected with several vaccines, such as equine influenza, Japanese encephalitis and Getah virus vaccines. And, horses exhibiting clinic- al pyrexia or some symptoms of infectious diseases are serologically examined for viruses, such as equine herpesvirus type 1 (EHV-1), equine rhinovirus type 1 (ERhV$1)$, rotavirus and equine adenovirus (EAdV). These agents are known as major causative ones of epizootics, but vaccines against them are never applied among racehorses in Japan.

This paper reports the results of the serological survey to detect the cause of pyrexia of racehorses for considering the counterpart to prevent the infectious diseases in the T. C.

\section{MATERIALS AND METHODS}

Horse populations: The Ritto T. C. is in Shiga Prefecture in the western part of 
Table 1. Number of racehorses in the Ritto Training Center in 1980

\begin{tabular}{crrrrrrrrrrrrrrr}
\hline Age & Jan. Feb. Mar. Apr. May Jun. Jul. Aug. Sep. Oct. Nov. Dec. & Total \\
\hline 2 & 18 & 36 & 86 & 610 & 485 & 521 & 524 & 643 & 895 & 1041 & 1106 & 1149 & 6644 \\
3 & 1101 & 1109 & 933 & 1300 & 731 & 619 & 338 & 474 & 538 & 434 & 507 & 484 & 8396 \\
4 and more & 884 & 847 & 656 & 998 & 556 & 301 & 256 & 352 & 445 & 424 & 428 & 413 & 6560 \\
\hline Entered $\left.^{a}\right)$ & 258 & 223 & 276 & 370 & 347 & 282 & 228 & 207 & 367 & 397 & 301 & 268 & 3424 \\
\hline
\end{tabular}

a) Almost the same number of horses left.

Japan, and Miho T. C. is in Ibaraki Prefecture in the eastern part of Japan. At each T. C., 1,200 to 2,100 racehorses are trained and accommodated in 114 to 123 sheds in 42 to $48 \mathrm{ha}$. The racehorses are transported to race courses except local ones from the $T$. C. every time for each race. During the season of local races, racehorses are transported and stay long in local race courses mainly in July and August. On the other hand, about 200 to 400 racehorses are replaced with new horses every month. The age distribution of racehorses and the number of replaced horses at the Ritto T. C. in 1980 are shown in Table 1.

Serum samples: Paired serum samples were taken from horses exhibiting clinical pyrexia with body temperature exceeding $38.5^{\circ} \mathrm{C}$ at the clinic of each T. C., that is acute stage and the convalescent stage. The convalescent stage began about 2 weeks after the acute stage. The samples were stored $-20^{\circ} \mathrm{C}$ until use for testing.

Complement fixation (CF) test: Sera were tested for antibodies against the $\mathrm{HH}-1$ strain of EHV-1 (provided by Dr. T. Shimizu, of the National Institute of Animal Health; NIAH), the T-1 strain of EAdV-1 (provided by Dr. W. H. McCollum, of the University of Kentucky), and the Lincoln strain of bovine rotavirus (provided by Dr. M. Kodama, of the NIAH) by CF test.

Antigens used were prepared as follows. The infected culture fluid and cell debris of RK-13, MDCK or MA-104 cells were concentrated by polyethylene glycol No. 6,000 at $10 \%(\mathrm{w} / \mathrm{w})$ and sodium chloride at $3 \%$ $(\mathrm{w} / \mathrm{w})$ and treated with ultrasonication. The resulting product was centrifuged at $6,000 \times$ $\mathrm{g}$ for $30 \mathrm{~min}$. The supernatant obtained was used as antigen.

The comparative $\mathrm{CF}$ test was conducted by the $\mathrm{CH}_{50}$ method as developed by the Centers for Disease Control of the U. S. A. and modified by Inoue [15]. In the modified method, $0.05 \mathrm{~m} l$ of five units of guinea pig complement, $0.025 \mathrm{~m} l$ of four units of antigen, $0.025 \mathrm{~m} l$ of a serum sample, from which serial two-fold dilutions were prepared, and $0.05 \mathrm{~m} l$ of $1.7 \%$ sensitized sheep red blood cells were used. The antibody titer was expressed with the reciprocal of the highest dilution that had inhibited hemolysis more than $50 \%$.

Virus neutralization (VN) test: Antibody against the NM-11 strain of ERhV-1 (provided by Dr. W. H. McCollumn, of the University of Kentucky) was detected by the VN test. A microtiter assay essentially the same as that described by Bibrack and Hartl [1] was used. In it, $0.05 \mathrm{~m} l$ of virus $(100$ $\mathrm{TCID}_{50}$ ) was mixed with an equal amount of a serial two-fold diluted serum in flatbottomed microplate (Nunc, Roskilde, Denmark). Vero cells $\left(1 \times 10^{6}\right.$ of cells in $0.075 \mathrm{~m} l$ ) were added to the resulting mixture after incubation at $37^{\circ} \mathrm{C}$ for $1 \mathrm{hr}$. The antibody titer was expressed as the reciprocal of the highest serum dilution that had neutralized the virus completely.

Status of the infection: When a horse showed a serum antibody titer in the con- 
Table 2. Distribution of horses with pyrexia in each month in the Ritto and Miho Training Centers (T. C.) from 1980 to 1985

\begin{tabular}{llrrrrrrrrrrrrrrr}
\hline Year & T. C. Jan. Feb. Mar. Apr. May Jun. Jul. Aug. Sep. Oct. Nov. Dec. & Total \\
\hline 1980 & Ritto & 29 & 36 & 15 & 13 & 11 & 16 & 49 & 24 & 44 & 10 & 17 & 19 & 283 \\
1980 & Miho & 196 & 39 & 17 & 20 & 19 & 15 & 11 & 15 & 20 & 23 & 15 & 39 & 429 \\
1981 & Ritto & 27 & 23 & 14 & 4 & 54 & 48 & 15 & 22 & 46 & 33 & 62 & 55 & 443 \\
1981 & Miho & 100 & 59 & 27 & 26 & 74 & 38 & 15 & 14 & 19 & 66 & 66 & 43 & 547 \\
1982 & Ritto & 60 & 75 & 29 & 43 & 42 & 27 & 38 & 40 & 46 & 25 & 39 & 36 & 500 \\
1982 & Miho & 20 & 19 & 20 & 25 & 10 & 24 & 24 & 22 & 56 & 37 & 24 & 37 & 318 \\
1983 & Ritto & 55 & 49 & 33 & 25 & 29 & 40 & 66 & 24 & 28 & 23 & 10 & 6 & 388 \\
1983 & Miho & 80 & 44 & 26 & 14 & 6 & 10 & 21 & 33 & 27 & 27 & 17 & 14 & 319 \\
1984 & Ritto & 34 & 15 & 11 & 16 & 17 & 31 & 11 & 1 & 13 & 16 & 17 & 5 & 187 \\
1984 & Miho & 17 & 17 & 12 & 10 & 11 & 18 & 7 & 0 & 7 & 3 & 6 & 2 & 110 \\
1985 & Ritto & 10 & 4 & 21 & 15 & 16 & 23 & 57 & 18 & 13 & 19 & 12 & 5 & 213 \\
1985 & Miho & 5 & 4 & 4 & 11 & 14 & 5 & 16 & 11 & 18 & 7 & 10 & 7 & 112 \\
\hline Total & Ritto & 215 & 202 & 123 & 156 & 169 & 185 & 236 & 129 & 190 & 126 & 157 & 126 & 2014 \\
Total & Miho & 418 & 182 & 106 & 106 & 134 & 110 & 94 & 95 & 147 & 163 & 138 & 142 & 1835 \\
\hline Total & Both & 633 & 384 & 229 & 262 & 303 & 295 & 330 & 224 & 337 & 289 & 295 & 268 & 3849 \\
& T. C. 's & & & & & & & & & & &
\end{tabular}

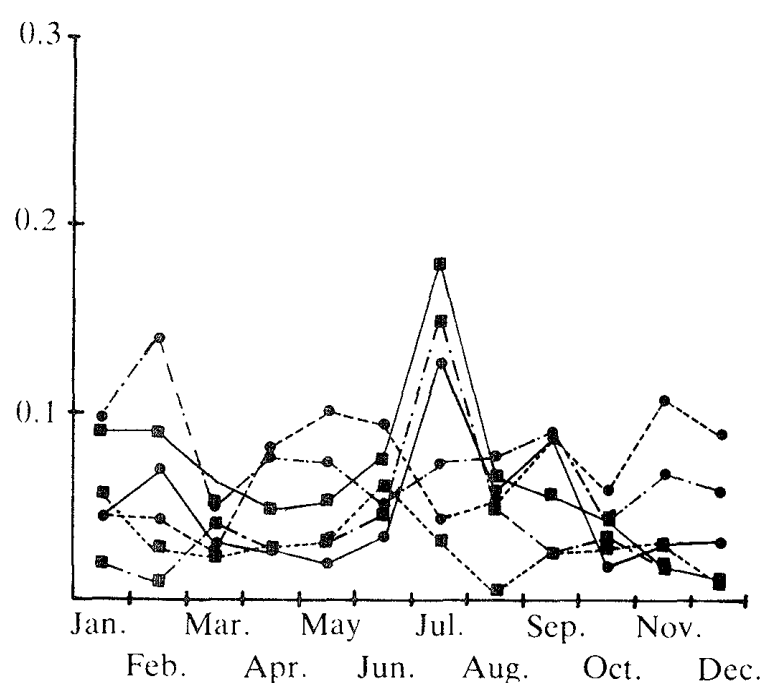

Fig. 1. Pyrexia ratio of horses stabled in the Ritto Training Center. The ratio was calculated with total number of horses with pyrexia/total number of horses in training center in each month. $1980,-$ $1984,-$ - -1985 .

valescent stage which was eight times as high as that shown in the acute stage, the horse was regarded as infected with the virus tested.

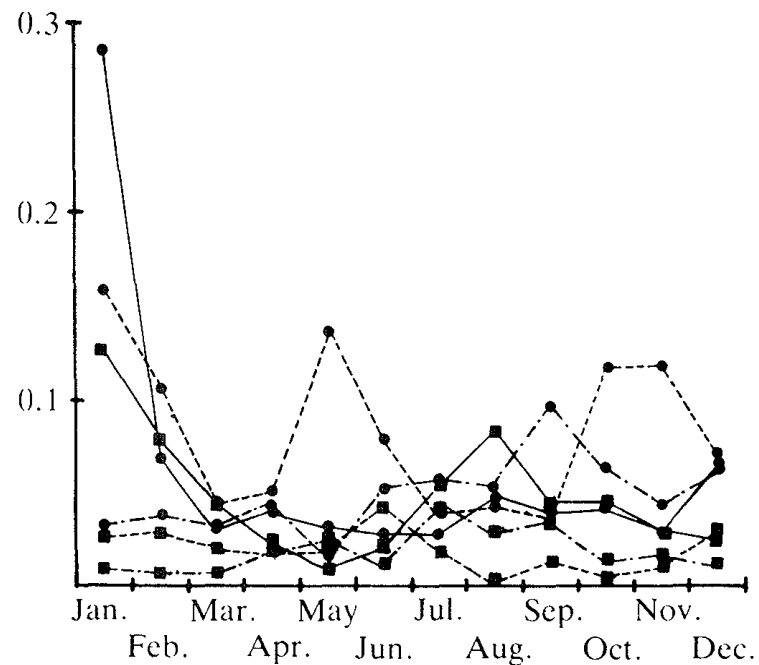

Fig. 2. Pyrexia ratio of horses stabled in the Miho Training Center. The ratio was calculated with total number of horses with pyrexia/total number of horses in training center in each month. $1980,--1981,-1982,-1-1983$, $1984,-1965$.

\section{RESULTS}

Number of horses with pyrexia in each month: The numbers of horses with pyrexia 
Table 3. Distribution of horses with seroconversion to equine herpesvirus type 1 in each month in the Ritto and Miho Training Centers (T. C.) from 1980 to 1985

\begin{tabular}{rrrrrrrrrrrrrrrr}
\hline Year & T. C. Jan. Feb. Mar. Apr. May Jun. Jul. Aug. Sep. Oct. Nov. Dec. & Total \\
\hline 1980 & Ritto & 7 & 9 & 0 & 0 & 0 & 0 & 0 & 0 & 0 & 0 & 0 & 0 & 16 \\
1980 & Miho & 96 & 5 & 0 & 0 & 0 & 0 & 0 & 0 & 0 & 0 & 0 & 0 & 101 \\
1981 & Ritto & 1 & 0 & 0 & 4 & 5 & 0 & 0 & 0 & 0 & 0 & 0 & 0 & 10 \\
1981 & Miho & 53 & 23 & 7 & 0 & 4 & 0 & 0 & 0 & 0 & 0 & 0 & 0 & 87 \\
1982 & Ritto & 21 & 47 & 1 & 0 & 0 & 0 & 0 & 0 & 0 & 0 & 0 & 8 & 77 \\
1982 & Miho & 0 & 1 & 4 & 4 & 0 & 0 & 0 & 0 & 0 & 0 & 0 & 17 & 26 \\
1983 & Ritto & 20 & 21 & 8 & 0 & 0 & 0 & 0 & 0 & 0 & 0 & 0 & 2 & 51 \\
1983 & Miho & 47 & 8 & 1 & 0 & 0 & 0 & 0 & 0 & 0 & 0 & 0 & 0 & 56 \\
1984 & Ritto & 23 & 7 & 0 & 0 & 0 & 0 & 0 & 0 & 0 & 0 & 0 & 1 & 31 \\
1984 & Miho & 0 & 5 & 3 & 1 & 0 & 0 & 0 & 0 & 0 & 0 & 0 & 1 & 10 \\
1985 & Ritto & 0 & 0 & 3 & 6 & 0 & 0 & 0 & 0 & 0 & 0 & 0 & 5 & 14 \\
1985 & Miho & 1 & 1 & 2 & 7 & 0 & 0 & 0 & 0 & 0 & 0 & 0 & 1 & 12 \\
\hline Total & Ritto & 72 & 84 & 12 & 10 & 5 & 0 & 0 & 0 & 0 & 0 & 0 & 16 & 199 \\
Total & Miho & 197 & 43 & 17 & 12 & 4 & 0 & 0 & 0 & 0 & 0 & 0 & 19 & 292 \\
\hline Total & Both & 269 & 127 & 29 & 22 & 9 & 0 & 0 & 0 & 0 & 0 & 0 & 35 & 491 \\
& T. C.'s & & & & & & & & & & & \\
\hline
\end{tabular}

at both T. C.'s in every month are presented in Table 2. The maximum total number per year was observed in 1981 at the Miho T. C. and in 1982 at the Ritto T. C. It declined year by year thereafter. In 1985, however, it was a little larger than in 1984. A total number of horses which manifested pyrexia among present survey was 3,849 .

In Figs. 1 and 2, the percentages of horses with pyrexia per total number of horses accommodated in each $\mathrm{T}$. C. in a month were presented. The mean value of each month was $0.0501 \pm 0.0395$ (M \pm S.D.). The upper $90 \%$ confidence limit was 0.115 . Among these peaks 9 peaks in July, 1980, 1983 and 1985, and February, 1982 in the Ritto T. C., and in January, 1980, and in January, May, October to November, 1981, and in January, 1983 in the Miho T. C. exceeded the upper $90 \%$ confidence limit.

Serology for EHV-1: Outbreaks of EHV1 infection were demonstrated at both $\mathrm{T}$. C.'s in winter to spring every year (Table 3 ). At the Miho T. C. in January and February,
1980, 101 horses showed seroconversion; that is the widest spread of this infection in the survey. At the Miho T. C. 83 horses exhibited seroconversion over the period from January to March, 1981. Thirty-two to 73 horses showing seroconversion were observed at the Ritto T. C. in January to March, 1982, in December, 1982 to March, 1983, and in December, 1983 to February, 1984, and at the Miho T. C. in December, 1982 to March, 1983. Four to 16 horses showed seroconversion in other seasons, some time from February to May.

Serology for ERhV-1: Epizootics of ERhV-1 were demonstrated (Table 4). At the Miho T. C. over the period from December, 1980, to February, 1981, 12 horses exhibited seroconversion; that is, the widest spread in the present survey. In the other spread, 1 to 3 horses showed seroconversion in one month.

Serology for rotavirus: Epizootic of rotavirus was demonstrated at the Miho T. C. in May to July and November to December, 
Table 4. Distribution of horses with seroconversion to equine rhinovirus type 1 in each month in the Ritto and Miho Training Centers (T. C.) from 1980 to 1985

Year T. C. Jan. Feb. Mar. Apr. May Jun. Jul. Aug. Sep. Oct. Nov. Dec. Total

\begin{tabular}{rlrlllllllllllr}
\hline 1980 & Ritto & 1 & 1 & 0 & 0 & 1 & 0 & 0 & 0 & 1 & 0 & 0 & 1 & 5 \\
1980 & Miho & 3 & 2 & 0 & 1 & 2 & 1 & 0 & 0 & 1 & 0 & 0 & 2 & 12 \\
1981 & Ritto & 2 & 1 & 0 & 2 & 2 & 0 & 0 & 0 & 3 & 0 & 0 & 0 & 10 \\
1981 & Miho & 7 & 3 & 0 & 2 & 0 & 0 & 0 & 0 & 2 & 2 & 3 & 2 & 21 \\
1982 & Ritto & 0 & 0 & 0 & 1 & 1 & 2 & 0 & 0 & 0 & 0 & 0 & 0 & 4 \\
1982 & Miho & 1 & 1 & 1 & 2 & 0 & 0 & 2 & 0 & 1 & 2 & 0 & 0 & 10 \\
1983 & Ritto & 0 & 2 & 2 & 1 & 0 & 0 & 0 & 0 & 0 & 0 & 2 & 0 & 7 \\
1983 & Miho & 1 & 0 & 0 & 0 & 0 & 0 & 0 & 0 & 0 & 1 & 0 & 2 & 4 \\
1984 & Ritto & 1 & 0 & 2 & 1 & 3 & 0 & 0 & 0 & 0 & 2 & 0 & 0 & 9 \\
1984 & Miho & 1 & 0 & 2 & 0 & 1 & 1 & 0 & 0 & 0 & 1 & 0 & 0 & 6 \\
1985 & Ritto & 0 & 0 & 0 & 0 & 0 & 0 & 0 & 0 & 0 & 0 & 0 & 0 & 0 \\
1985 & Miho & 0 & 1 & 0 & 0 & 1 & 0 & 0 & 0 & 1 & 0 & 0 & 0 & 3 \\
\hline Total & Ritto & 4 & 4 & 4 & 5 & 7 & 2 & 0 & 0 & 4 & 2 & 2 & 1 & 35 \\
Total & Miho & 13 & 7 & 3 & 5 & 4 & 2 & 2 & 0 & 5 & 6 & 3 & 6 & 56 \\
\hline Total & Both & 17 & 11 & 7 & 10 & 11 & 4 & 2 & 0 & 9 & 8 & 5 & 7 & 91 \\
& T. C.'s & & & & & & & & & & & & & \\
\hline
\end{tabular}

Table 5. Distribution of horses with seroconversion to rotavirus in each month in the Ritto and Miho Training Centers (T. C.) from 1980 to 1985

\begin{tabular}{rrrrrrrrrrrrrrrrrr}
\hline Year & T. C. Jan. Feb. Mar. Apr. May Jun. Jul. Aug. Sep. Oct. Nov. Dec. & Total \\
\hline 1980 & Ritto & 0 & 0 & 0 & 0 & 0 & 0 & 0 & 0 & 0 & 0 & 0 & 0 & 0 \\
1980 & Miho & 0 & 0 & 0 & 0 & 0 & 0 & 0 & 0 & 0 & 0 & 0 & 0 & 0 \\
1981 & Ritto & 0 & 0 & 0 & 0 & 0 & 0 & 0 & 0 & 0 & 0 & 0 & 0 & 0 \\
1981 & Miho & 0 & 0 & 0 & 0 & 6 & 2 & 1 & 0 & 0 & 0 & 3 & 5 & 17 \\
1982 & Ritto & 0 & 3 & 1 & 1 & 0 & 0 & 0 & 0 & 0 & 0 & 0 & 1 & 6 \\
1982 & Miho & 1 & 0 & 0 & 1 & 0 & 0 & 0 & 0 & 0 & 0 & 0 & 0 & 2 \\
1983 & Ritto & 1 & 1 & 0 & 0 & 0 & 0 & 0 & 0 & 0 & 0 & 0 & 0 & 2 \\
1983 & Miho & 12 & 7 & 0 & 0 & 0 & 0 & 1 & 0 & 0 & 1 & 2 & 1 & 24 \\
1984 & Ritto & 0 & 0 & 0 & 1 & 1 & 0 & 0 & 0 & 0 & 0 & 0 & 0 & 2 \\
1984 & Miho & 0 & 0 & 0 & 0 & 0 & 1 & 0 & 0 & 0 & 0 & 0 & 0 & 1 \\
1985 & Ritto & 0 & 0 & 0 & 1 & 1 & 0 & 2 & 0 & 0 & 0 & 0 & 0 & 4 \\
1985 & Miho & 0 & 0 & 0 & 0 & 0 & 0 & 0 & 0 & 1 & 1 & 1 & 3 & 6 \\
\hline Total & Ritto & 1 & 4 & 1 & 3 & 2 & 0 & 2 & 0 & 0 & 0 & 0 & 1 & 14 \\
Total & Miho & 13 & 7 & 0 & 1 & 6 & 3 & 2 & 0 & 1 & 2 & 6 & 9 & 50 \\
\hline Total & Both & 14 & 11 & 1 & 4 & 8 & 3 & 4 & 0 & 1 & 2 & 6 & 10 & 64 \\
& T. C.'s & & & & & & & & & & & & \\
\hline
\end{tabular}


Table 6. Distribution of horses with seroconversion to equine adenovirus in each month in the Ritto and Miho Training Centers (T. C.) from 1980 to 1985

\begin{tabular}{cccccccccccccccc}
\hline Year & T. C. Jan. Feb. Mar. Apr. May Jun. Jul. Aug. Sep. Oct. Nov. Dec. & Total \\
\hline 1980 & Ritto & 0 & 0 & 0 & 0 & 2 & 0 & 0 & 0 & 0 & 0 & 0 & 0 & 2 \\
1980 & Miho & 1 & 0 & 0 & 0 & 0 & 0 & 0 & 0 & 0 & 0 & 0 & 0 & 1 \\
1981 & Ritto & 1 & 0 & 0 & 0 & 0 & 1 & 0 & 0 & 0 & 0 & 0 & 0 & 2 \\
1981 & Miho & 0 & 0 & 0 & 0 & 0 & 0 & 0 & 0 & 0 & 0 & 0 & 0 & 0 \\
1982 & Ritto & 0 & 1 & 0 & 0 & 0 & 0 & 0 & 0 & 0 & 0 & 2 & 3 & 6 \\
1982 & Miho & 0 & 0 & 0 & 1 & 1 & 1 & 2 & 1 & 0 & 1 & 0 & 0 & 7 \\
1983 & Ritto & 0 & 0 & 0 & 0 & 0 & 0 & 0 & 0 & 1 & 0 & 0 & 0 & 1 \\
1983 & Miho & 1 & 0 & 0 & 0 & 0 & 0 & 0 & 0 & 0 & 0 & 0 & 0 & 1 \\
1984 & Ritto & 0 & 0 & 0 & 0 & 0 & 0 & 0 & 0 & 0 & 0 & 0 & 0 & 0 \\
1984 & Miho & 0 & 0 & 0 & 0 & 0 & 0 & 0 & 0 & 0 & 0 & 0 & 0 & 0 \\
1985 & Ritto & 0 & 0 & 0 & 0 & 0 & 0 & 0 & 0 & 0 & 0 & 1 & 0 & 1 \\
1985 & Miho & 0 & 0 & 0 & 0 & 0 & 0 & 1 & 0 & 1 & 0 & 0 & 0 & 2 \\
\hline Total & Ritto & 1 & 1 & 0 & 0 & 2 & 1 & 0 & 0 & 1 & 0 & 3 & 3 & 12 \\
Total & Miho & 2 & 0 & 0 & 1 & 1 & 1 & 3 & 1 & 1 & 1 & 0 & 0 & 11 \\
\hline Total & Both & 3 & 1 & 0 & 1 & 3 & 2 & 3 & 1 & 2 & 1 & 3 & 3 & 23 \\
& T. C. 's & & & & & & & & & & & & \\
\hline
\end{tabular}

Table 7. Age distribution of racehorses showing seroconversion to viruses

\begin{tabular}{crrrr}
\hline $\begin{array}{c}\text { Age in } \\
\text { Years }\end{array}$ & EHV-1 $^{\text {a) }}$ & Rota $^{\mathrm{b})}$ & ERhV-1 $^{\mathrm{c})}$ & EAdV $^{\mathrm{d})}$ \\
\hline 2 & 94 & 34 & 63 & 19 \\
3 & 338 & 20 & 20 & 7 \\
4 & 48 & 6 & 8 & 0 \\
5 & 11 & 4 & 0 & 0 \\
\hline Total & 491 & 64 & 91 & 26 \\
\hline Mean & 2.96 & 2.73 & 2.44 & 2.27 \\
\hline
\end{tabular}

a) Equine herpesvirus type 1 .

b) Rotavirus.

c) Equine rhinovirus type 1 .

d) Equine adenovirus.

1981, and January to February, 1983 and at the Ritto T. C. in February to April, 1982, and in December, 1982 to February, 1983 (Table 5). The number of horses showing seroconversion on one occasion was larger in rotavirus infection than in ERhV-1 infection. The total number of horses infected with rotavirus was smaller than that with
EHV-1 or ERhV-1 in the present survey. Of the horses showing seroconversion, $55.0 \%$ was found in winter, from December to February.

Serology for EAdV: A total 23 horses showed seroconversion to EAdV (Table 6). The maximum number of horses showing seroconversion in one month was only three at the Ritto T. C. in December, 1982.

Age distribution of infected horses: The age distribution of horses infected with the viruses is shown in Table 7. More than $50 \%$ of horses infected with ERhV-1, EAdV, and rotavirus were 2 years old, although $68.9 \%$ of EHV-1-infected horses were 3 years old. Of the EAdV-infected horses, $73.1 \%$ (19 in 26) were 2 years old and none were more than 4 years old. The mean age of infected horses were 2.96 years for EHV-1, 2.73 for rotavirus, 2.44 for ERhV-1 and 2.27 for EAdV.

Percentages of virus as cause of infection: Of 3,849 pyretic horses, paired serum samples were taken from 2,852 horses and 
examined for four viruses. And, 491 $(17.2 \%), 91(3.2 \%), 64(2.2 \%)$ and 23 $(0.8 \%)$ of examined horses showed seroconversion to EHV-1, ERhV-1, rota and $\mathrm{EAdV}$, respectively. In the remaining $76.5 \%$ of examined horses, the cause of pyrexia was not determined.

\section{DISCUSSION}

From the present sero-epizootiological study conducted for 6 consecutive years since 1980 , it was strongly suggested that in $23.8 \%$ of all the horses with pyrexia, this symptom might have been caused by some viral agents. Although the spread of viruses did not threaten races actually, the infection influenced training and participation in races of individual racehorses. Since pyrexia is a symptom of respiratory or systemic infectious disease, it is important to determine the cause of pyrexia to prevent such infectious disease. In $76.5 \%$ of horses the cause of pyrexia was not determined. As the cause of pyrexia in these horses, heat stroke, fatigue, bacteria and unknown viral infections were considered. On the other hand, nine peaks that exceeded the $90 \%$ confidence limit of percentages of horses with pyrexia per total stabled horses were observed. Among these, four peaks observed in January and February from 1980 to 1983 were considered to be due to infection with EHV-1 and other respiratory agents. Three peaks observed in July, 1980, 1983 and 1985 were considered to be due to shipping fever or heat stroke. Remaining one peak was observed in May, 1981 in the Miho T. C., and a smaller peak was observed in the Ritto T. C. at the same time. In this season, from spring to early summer, such phenomenon was sometime observed among horse population. The other symptoms were diarrhea, edema of hind legs and 'rashes on several parts of the body, although diseased horses did not show increase of antibody titers at the convalescent stage to any viruses tested, including Getah and Japanese encephalitis viruses. It is possible that there may be an unknown infectious disease in this season.

Of the horses showing seroconversion, $74.9 \%$ manifested pyrexia caused by EHV1. This fact suggests that pyrexia in some racehorses may have been prevented by vaccination against EHV-1. In Japan EHV1 vaccine is only one biological product which is officially permitted to use for the prevention of abortion by this virus. It might be necessary to apply already or newly developed vaccine to the prevention of the respiratory disease at the $T$. C.

The spread of EHV-1 has been reported to be worldwide [2, 4-6, 10, 12, 16, 26, 32]. In Japan, subtype 1 of EHV-1 was introduced from the U.S.A. in 1967 by imported broodmares [18]. Before that time only subtype 2 had been found in Japan [27]. In the present survey, it was clarified that the spread of this infection showed a seasonal occurrence in winter to early spring, from December to March with a peak incidence in January, although on rearing or breeding farms the virus was found to spread in any season of the year $[23,29]$. The percentage of 3 years old among horses showing seroconversion to EHV-1 was two times higher than those to other viruses. The mean age of horses showing seroconversion to EHV-1 was the highest among the examined viruses.

The spread of ERhV-1 on rearing farms of the J. R. A. [21, 29], as well as on a breeding and rearing farms [23], was reported by several groups of investigators. As a result, it was made clear that this virus had been spread almost every year among rearing horses, although the number of infected horses was relatively small at the $T$. C. The infected horses were rather young, or under four years old. From these facts, it was considered that infection with ERhV-1 
might be rare among racehorses. Most racehorses had already antibodies to this virus, since they had been exposed to infection on rearing or breeding farms.

Serological reactors against the Lincoln strain of bovine rotavirus were found in $65.7 \%$ of foals and $27.0 \%$ of racehorses in Japan in 1979 [14]. After that, equine rotavirus was isolated from foals associated with diarrhea in tissue culture by Imagawa $e t$ al. [13]. Actual epizootics had never been noted among racehorses before the present survey was conducted. Horses showing seroconversion were relatively old. As there is a tendency for this virus to infect human beings repeatedly [22], it is considered that reinfected horses may have been included in those horses showing seroconversion.

In Japan a sero-epizootiological study on EAdV was undertaken by Kamada in the Tokyo Racecourse in 1977 [17]. As the results, $44.3 \%$ of racehorses had CF antibody, although the number of sero-positive horses was very small in the present survey. From these results, it is considered that the spread of this virus has been much reduced in the past 13 years. The mean age was lower in horses showing seroconversion to EAdV than in horses showing seroconversion to any other virus studied in the present survey.

EHV-1, ERhV-1 and rotavirus exhibited a seasonal characteristic in spread. EHV-1 spread in winter and early spring, from December to May. Rotavirus spread in winter, November to February. In contrast, ERhV- $\mathbb{1}$ spread not only in the cold season, but in April to May, and in September. In Japan, the daily variations of atmospheric temperature are large in these months. Clinical signs of infection with this virus were rarely observed on a rearing farm, even when antibody titer increased in most horses on the farm $[21,23,29]$. These phenomena suggest that the pathogenicity of this virus may be very weak. If the condition of an infected horse is affected with stress from changes of weather, the horse will show clinical signs.

There are two papers published to report about sero-epizootiological studies on viruses in race tracks in countries other than Japan. In Canada, the spread of equine influenza virus and EHV-1 was reported to have occurred from 1973 to 1975 [11] and from 1977 to 1978 [24]. Serological surveys were conducted on the horse population, except horses kept in race tracks, in these countries. They revealed the spread of equine influenza virus types 1 and $2[2,24$, 32], EHV-2 [12, 24], EAdV-1 to 3 [2, 23, 32], ERhV-1 to 3 [2, 11, 24], reovirus type 1 to $3[3,28,32]$ and parainfluenza virus type $3[12,31]$. In Japan, an epizootic of equine influenza occurred from 1971 to 1972 [19]. Since then, vaccines of A/equine/Prague/56, $\mathrm{A} /$ equine/Miami/63 and A/equine/Tokyo/71 were used in most racehorses in autumn every year up to 1985 . These strains were changed to A/equine/Newmarket/77, A/ equine/Tokyo/71 and A/equine/Kentucky/ 81 , respectively, in 1985 . No epizootics of equine influenza have occurred in Japan yet. Serological reactors to reovirus types 1 to 3 [Imagawa et al. oral presentation at the 100th Meetings for Japanese Society of Veterinary Science, Tokyo], EHV-2 [20, 30], Akabanevirus [9], picornaviruses [8], and Chlamydia psittaci [Ogawa et al. oral presentation at the 97th Meetings for Japanese Society of Veterinary Science, Tokyo] have been reported in Japanese horse population. We are now testing these agents, including toxoplasma reported in the U.S.A. [25] and Chlamydia trachomatis, to survey for serum samples examined in present study. Results showing that these pathogens rarely affect racehorses will be realized in the near future.

Introduction of enzyme-linked immunosorbent assay (ELISA) has been made progress in the titration of antibody to 
infectious agents of horses [31]. ELISA is highly sensitive and can be used for the evaluation of a large number of serum samples. It is a powerful means for serological study.

\section{REFERENCES}

1. Bibrack, B., and Hartl, G. 1971. Mikrotest zum Nachweiss neutralizierender antiherpes gegen das Rhinopneumonitis virus der Pferde. Zbl. Vet. Med. B. 18: 517-526.

2. Burrows, R., Goodridge, D., Denyer, M., Hutchings, G., and Frank, C. J. 1982. Equine influenza infections in Great Britain, 1979. Vet. Rec. 110: 494-497.

3. Corner, M., Kalica, A., Kita, J., Quick, S., Schiff, E., Joubert, J., and Gillespie, J. 1984. Isolation and characteristics of an equine reovirus type 3 and antibody prevalence survey to reoviruses in horses located in New York State. Vet. Microbiol. 9: 15-25.

4. Dinter, Z., and Klingeborn, B. 1976. Serological study of an outbreak of paresis due to equid herpesvirus 1 (EHV-1). Vet. Rec. 99: 10-12.

5. Doll, E. R., and Bryans, J. T. 1963. Epizootiology of equine rhinopneumonitis. J. Am. Vet. Med. Assoc. 142: 31-37.

6. Fretz, P. B., Babiuk, L. A., and McLaughlin, B. 1979. Equine respiratory disease on the Western Canadian racetracks. Can. Vet. J. 20: 58-61.

7. Fukunaga, Y., Ando, Y., Kamada, M., Imagawa, H. Wada, R., Kumanomido, T., Akiyama, Y., Watanabe, O., Niwa, K., Takenaga, S., Shibata, M., and Yamamoto, T. 1981. An outbreak of Getah virus infection in horses. Clinical and epizootiological aspects at the Miho Training Center in 1978. Bull. Equine Res. Inst. 18: 94-102.

8. Fukunaga, Y., Kumanomido, T, Imagawa, H., Ando, Y., Kamada, M., Wada, R., and Akiyama, Y. 1981. Isolation of picornavirus from horses associated with Getah virus infection. Jap. J. Vet. Sci. 43: 569-572.

9. Furuya, Y., Shoji, H., Inaba, Y., and Matumoto, M. 1980. Antibodies to Akabane virus in horses, sheep, and goats in Japan. Vet. Microbiol. 5: 239-242.

10. Greenwood, R. E. S. 1979. Equine rhinopneumonitis outbreak at Newmarket. Vet. Rec. 104: 534-535.

11. Hamre, D. 1966. Virologic studies of acute respiratory disease in young adults. IV. Virus isolations during four years of surveillance. Am. J. Epidemiol. 83: 238-249.
12. Hofer, B., Steck, F., Gerber, H., Lohrer, J., Nicklet, J., and Paccaud, M. F. 1972. An investigation of the etiology of viral respiratory disease in a Remoun Depot. Proc. 3rd. Int. Conf. Equine Infectous Diseases, 1972: 527-545.

13. Imagawa, H., Ando, Y., Sugiura, T., Wada, R., Hirasawa, K., and Akiyama, Y. 1981. Isolation of foal rotavirus in MA-104 cells. Bull. Equine Res. Inst. 18: 119-128.

14. Imagawa, H., Ando, Y., and Akiyama, Y. 1979. A survey on complement fixation antibody against bovine rotavirus in light horses in Japan. Exp. Rep. Equine Hlth Lab. 16: 23-29.

15. Inoue, S. 1978. Complement fixation test. pp. 73-83. In: Examination of virus and rickettia., 2nd ed. (Yanagisawa, K. ed.), Society for Japanese Public Hygiene, Tokyo (In Japanese).

16. Jana, A. M., Pandya, G., and Rao, K. M. 1980. Evidence of complement fixing antibodies against equine rhinopneumonitis virus in army horses and mules. Curr. Sci. 49: 575-576.

17. Kamada, M. 1978. Comparison of the four serological tests for detecting antibodies against equine adenovirus. Exp. Rep. Equine Hlth Lab. 15: 91-96.

18. Kawakami, Y., Nakano, K., Kume, T., Hiramune, T., and Murase, N. 1970. Abortion by equine rhinopneumonitis virus in Hidaka, Hokkaido district in Japan. Bull. Nat. Inst. Anim. Hlth 61: 9-16. (In Japanese).

19. Kono, Y., Ishikawa, K., Fukunaga, Y., and Fujino, M. 1972. The first outbreak of equine influenza in Japan. Nat. Inst. Anim. Hlth Quart. 12: $183-187$.

20. Kono Y., and Kobayashi, K. 1964. Cytopathogenic equine orphan (CEO) virus in horse kidney cell culture. II. Immunological studies of CEO virus. Nat. Inst. Anim. Hlth Quart. 4: 21-27.

21. Kumanomido, T., and Akiyama, Y. 1979. Serological survey of equine rhinovirus serotype 1 among light horses in Japan. Exp. Rep. Equine Hlth Lab. 16: 15-22.

22. Mata, L., Simhon, A., Urrutia, J. J., Kronmal, R. A., Fernandez, R., and Garcia, B. 1983. Epidemiology of rotaviruses in a cohort of 45 Guatemalan Mayan Indian children observed from birth to the age of three years. J. Infect. Dis. 148: 452-461.

23. Matsumura, T., Komano, M., Sugiura, T., and Fukunaga, Y. 1986. Sero-epizootiological study on viral diseases among horses in a breeding farm of Japan during a period from 1981 to 1985. Exp. Rep. Equine Hlth Lab. 23: 28-34.

24. Powell, D. G. 1975. Equine infectious repsiratory disease. Vet. Rec. 96: 30-34.

25. Riemann, H. P., Smith, A. T., Stormont, C., Ruppanner, R., Behymer, D. E., Suzuki, Y., 
Franti, C. E., and Verma, B. B. 1975. Equine toxoplasmosis: A survey for antibodies to toxoplasma gondii in horses. Am. J. Vet. Res. 36: 1797-1800.

26. Sherman, J., Mitchell, W. R., Martin, S. W., Thorsen, J., and Ingram, D. G. 1979. Epidemiology of equine upper respiratoy tract disease on Standardbred racetracks. Can J. Comp. Med. 43: 1-9.

27. Shimizu, T., Ishizaki, R., and Matsumoto, M. 1963. Survey of antibody to equine rhinopneumonitis virus in horse population in Japan. Bull. Nat Inst. Anim. Hlth 44: 11-17 (In Japanese).

28. Sturm, R. T., Lang, G. H., and Mitchell, W. R. 1980. Prevalence of reovirus 1,2 and 3 antibodies in Ontario racehorses. Can. Vet. J. 21: 206-209.

29. Sugiura, T., Ando Y., Masuzawa, H., Kuriyama, H., Ogawa, A., and Hirasawa, K. 1983. Sero- epizootiological studies on rearing horses on the Hidaka Rearing Farm from 1980 to 1983. Bull. Equine Res. Inst. 20: 48-54. (In Japanese).

30. Sugiura, T., Fukuzawa, Y., Kamada, M., Ando, Y., and Hirasawa, K. 1983. Isolation of equine herpesvirus type 2 from foals with pneumonitis. Bull. Equine Res. Inst. 20: 148-153.

31. Sugiura, T., Matsumura, T. and Fukunaga, Y. 1985. Diagnosis of equine infectious anemia by enzyme-linked immunosorbent assay with viral antigen purified by affinity chromatography. Bull. Equine Res. Inst. 23: 42-48.

32. Zmudzinski, J., Baczynski, Z., and SkukmowskaKryazkowska, D. 1980. Serological examinations of horses for the presence of antibodies against pneumotropic viruses. Bull. Vet. Inst. Pulawy 24: $1-4$.

要約

日本中央競馬会トレーニング・センターにおける発熱性疾患馬の血清疫学調査：杉浦健夫・松村富夫・福永昌 夫・平澤 澄（日本中央競馬会競走馬総合研究所栃木支所）—-1980１985年に日本中央競馬会トレーニング・ センターに所属する競走馬の発熱性疾患について血清疫学的に調査した。発熱馬総数は3,849頭で，血清が採取 された2,852頭中 669 頭 $(23.7 \%) に ，$ 馬ヘルペスウイルス 1 型 $(\mathrm{EHV}-1)$ ，馬ライノウイルス 1 型 $(\mathrm{ERhV}-1)$, ロタウイルスおよび馬アデノウイルス (EAdV) に対する抗体の上昇が認められ，EHV-1 が491頭 $(73.4 \%)$, ERhV-1が91頭 (13.6\%)，ロタウイルスが64頭（9.6\%)，EAdVが23䫓（3.4\%）であった。 EHV-1とロタウ イルスに対する抗体は，冬一初春に上昇し， ERhV-1 抗体は冬のみならず，初春および初秋にも上昇がみられ た. EHV-1 抗体上昇馬のうち, 満 3 歳馬の占める割合は他のウイルスの約 2 倍であり, ERhV-1 $\mathrm{EAdV} の$ 抗 体上昇馬はすべて満 4 または 3 歳以下であった。 EHV-1，口夕，ERhV-1 および EAdVの抗体上昇馬の平均年 秢はそれぞれ2.96, 2.73，2.44および2.27歳であった。 